12. Невский С.А. Антропогенная динамика нагорных лесов Саратовского Правобережья: автореф. дис. ... канд. биол. наук. Тольятти, 2001. 23 с.

13. Благовещенский В.В. Определитель растений Среднего Поволжья. Л.: Изд-во «Наука», 1984. 392 с.

14. Матвеев Н.М. Биоэкологический анализ флоры и растительности (на примере лесостепной и степной зоны). Самара: Изд-во «Самарский университет», 2006. 311 с.

15. Плаксина Т.И. Конспект флоры Волго-Уральского региона. Самара: Изд-во «Самарский университет», 2001. 388 с.

16. Сосудистые растения Самарской области / под ред. А.А. Устиновой, Н.С. Ильиной. Самара: Изд-во «Содружество», 2007. 400 с.
17. Михайлова И.Н., Вардания Е.В. Оценка антропогенного воздействия на дубравы г. Чебоксары методом дорожно-тропиночной сети // Изучение растительных ресурсов Волжско-Камского края: мат-лы всерос. науч.-практ. конф. (Чебоксары, 3-5 октября 2008 г.) / гл. ред. В.Г. Папченков. Чебоксары, 2008. С. 60-62.

18. Степанов М.В. Рекреационная трансформация пригородных лесов Саратова: дис. ... канд. биол. наук. Саратов, 2002. 237 с.

19. Алексеев В.А. Диагностика жизненного состояния деревьев и древостоев // Лесоведение. 1989. № 4. C. 51-57.

20. Матвеева Т.Б. Комплексная характеристика пригородных лесов окрестностей Самары: дис. ... канд. биол. наук. Саратов, 2015. 268 с.

\title{
SOIL AND VEGETATION COVER EVALUATION IN THE FORESTRY AREA «MEKHZAVODSKOY» OF THE SUBURBAN SAMARA FORESTRY ENTERPRISE AREA
}

(C) 2019

Matveeva Tatyana Borisovna, candidate of biological sciences, associate professor of Chair of Biology, Ecology and Methods of Teaching

Kazantsev Ivan Victorovich, candidate of biological sciences, associate professor

of Chair of Chemistry, Geography and Methods of Teaching, dean of Faculty of Natural Sciences and Geography

Molchatsky Sergey Lvovich, candidate of physical and mathematical sciences, associate professor

of Chair of Chemistry, Geography and Methods of Teaching

Samara State University of Social Sciences and Education (Samara, Russian Federation)

Abstract. The paper presents data on the state of soil and vegetation cover of oak forests of suburban forests near the village Mekhzavod. Being in the ring of large highways as well as located relatively close to Samara, they experience a complex impact of many adverse conditions. In the course of the study in these forest communities using the method of laying ecological profiles, we assessed a degree of recreational load impact on the vegetation cover of the green zone. The author estimated the percentage of road and path network development, described stages of recreational digression (for R.A. Karpisonova) and identified the main indicators of anthropogenic load, a vital status of major forest tree species and the factors contributing to its deterioration. The author also revealed a classification of soils with the help of laying soil profiles in different quarters and the subsequent chemical analysis of the selected samples. It is determined that the gray forest soils indicated for this area on the soil map of the Volga Region are not found. Taking into account the unsatisfactory state of the vegetation cover of the studied area, a number of recommendations for its rational use are proposed, which can further contribute to the preservation and improvement of these forests stability.

Keywords: suburban forests; forest community; oak forest; maple forest; lime forests; soil profile; environmental profile; anthropogenic impact; recreational load; road and path network; stage of recreational digression; relatively undisturbed area; vital status; forest; vegetation.

\section{ВЛИЯНИЕ ЗАПАСОВ ПРОДУКТИВНОЙ ВЛАГИ И КОЛИЧЕСТВА АТМОСФЕРНЫХ ОСАДКОВ НА УРОЖАЙНОСТЬ ПРИ УСЛОВИИ ПРЯМОГО ПОСЕВА СЕЛЬСКОХОЗЯЙСТВЕННЫХ КУЛЬТУР В РОСТОВСКОЙ ОБЛАСТИ}

(C) 2019

Мокриков Григорий Васильевич, кандидат сельскохозяйственных наук, научный сотрудник кафедры экологии и природопользования Академии биологии и биотехнологии им. Д.И. Ивановского

Минникова Татьяна Владимировна, младший научный сотрудник кафедры экологии и природопользования Академии биологии и биотехнологии им. Д.И. Ивановского

Казеев Камиль Шагидуллович, доктор географических наук, профессор кафедры экологии и природопользования Академии биологии и биотехнологии им. Д.И. Ивановского

Колесников Сергей Ильич, доктор сельскохозяйственных наук, профессор, заведующий кафедрой экологии и природопользования Академии биологии и биотехнологии им. Д.И. Ивановского Южный федеральный университет (г. Ростов-на-Дону, Российская Федерация)

Аннотацияя. Технологии обработки почвы, способствующие ресурсосбережению и повышению урожайности сельскохозяйственных культур, особенно в условиях сухости климата, все более активно внедряются в сельское хозяйство России. Однако, учитывая разнообразие почвенно-климатических условий на территории 
Мокриков Г.В., Минникова Т.В., Казеев К.Ш., Колесников С.И.

Влияние запасов продуктивной влаги и количества атмосферных осадков на урожайность ... 03.02 .00 - общая биология

России, необходимы исследования агроэкологического состояния агроландшафтов при их применении. В России за последние годы наблюдали повышение урожайности озимой пшеницы и подсолнечника. В течение 2014-2018 гг. в производственных условиях в Ростовской области изучали влияние технологии прямого посева (No-Till) на урожайность озимой пшеницы и подсолнечника. Урожайность подсолнечника и озимой пшеницы в значительной степени зависела от количества осадков в течение критического периода вегетации каждой сельскохозяйственной культуры. В 2014-2017 гг. урожайность озимой пшеницы в агроценозах при использовании технологии прямого посева повысилась на 26-114\%, подсолнечника - на 27-92\% по сравнению с традиционной технологией. Показано, что прямой посев по сравнению с традиционной технологией отвальной вспашки (традиционная обработка) способствует экономии моторного топлива, повышению урожайности сельскохозяйственных культур и понижению себестоимости основных сельскохозяйственных культур Ростовской области: озимой пшеницы и подсолнечника.

Ключевые слова: экосистема; экологичная технология; природоподобные технологии; агроценозы; влажность; вегетационный период; чернозем обыкновенный; прямой посев; нулевая технология; традиционная технология; ресурсосбережение; состояние почв; озимая пшеница; подсолнечник; урожайность; плодородие.

\section{Введение}

Численность населения Земли с каждым годом возрастает в среднем на 1,00-1,22\% (100,0-122,2 млн человек). Регулярное повышение численности населения вынуждает человека искать новые источники пищи и интенсивно осваивать новые сельскохозяйственные угодья или использовать уже имеющиеся. Наряду с необходимостью развития сельскохозяйственного сектора, возникает вопрос о рациональном использовании невозобновляемых источников энергии - нефти и газа. Последние годы в России активно обсуждается возможность экономии моторного топлива в сельском хозяйстве без ущерба урожайности выращиваемых культур и плодородия почв. Современные технологии обработки почвы включают в себя комплекс мероприятий по механической и химической обработке почвы: отвальная вспашка, чизелевание, внесение минеральных удобрений и обработка пестицидами и т.д. Различные приемы обработки почвы изменяют агрофизические свойства почв $[1$, с. $36-37 ; 2$, с. $5-6 ; 3$, p. $663-664 ; 4$, p. $233-$ 234]. Наиболее значительным является изменение почвенной структуры и уменьшение проницаемости почв по сравнению с традиционной обработкой почвы. При отвальной вспашке происходит нарушение почвенных агрегатов, в зависимости от атмосферных осадков наблюдают цементацию частиц почвы, а стабилизация структуры происходит благодаря деятельности почвенной макро-, мезо- и микрофауны [5, p. 66-67].

Традиционная обработка почв со вспашкой приводит к эрозии, дефляции, дегумификации, аридизации почв юга России, изменяя структуру почвы и связанные с экосистемой функции содержания углерода, выделения парниковых газов и сохранения влаги в почве $[6$, с. $416 ; 7$, с. 5-6]. При сокращении применения традиционной обработки почвы необходима рациональная, экономически выгодная и экологичная технология. К таким технологиям относят ряд приемов обработки, оказывающих минимальное воздействие на почву сельскохозяйственных угодий по аналогу природы. К таким природоподобным технологиям относят прямой посев, или No-Till. При прямом посеве можно сэкономить на потреблении моторного топлива, содержании углерода, снизить потребление гербицидов и уменьшить процессы эрозии почв [5, p. 66-67; 8, с. 21-22; 9, p. 87-88; 10, p. 15-17].

Эта технология обработки почвы широко распространена в США, Аргентине, Бразилии и ряде других стран мира $[5$, р. $66-67 ; 11$, с. $234 ; 12$, с. 3-4]. Ввиду отсутствия механической обработки прямой посев сохраняет почвенную структуру, пористость почв позволяет удерживать воду в почве в корнеобитаемой зоне, необходимой для роста и развития растений $[13$, p. 69-70]. Применение природоподобной технологии способствует, наряду с экономией ресурсов, повышению плодородия и снижению негативного воздействия на агроценозы. Для оценки приемов обработки почв на физическое состояние и структуру необходимо учитывать топографию местности, количество осадков и температуру почв $[14$, с. $763-$ $764 ; 15$, с. $106-107 ; 16$, p. 376-377].

Невысокая популярность таких природоподобных технологий в Ростовской области обусловлена низкой обеспеченностью сельского хозяйства высокопроизводительной сельскохозяйственной техникой и высокой стоимостью посевной техники. По соотношению видов обработки почвы к 2020 году в структуре посевных площадей Ростовской области наибольшая площадь пашни будет обработана поверхностной, мелкой обработкой и прямым посевом - 43,9\%, глубоким щелеванием, чизельной и плоскорезной обработками $-21,4 \%$, а глубокой отвальной вспашкой - только $12,5 \%$ [17, с. 243]. Применение технологии прямого посева в Ростовской области оказывает благоприятное воздействие на биологическое состояние почв. При прямом посеве наблюдают увеличение содержания углерода послеуборочных остатков сидеральных, поукосных, промежуточных, уплотнительных и пожнивных растений предыдущего урожая, растительной мульчи, преобразующейся в ходе деятельности микробиоты в гумус [4, р. 233234; 5, p. 66-67]. Технология прямого посева оказывает благоприятное воздействие на процесс нитрификации подо льном, ячменем и озимой пшеницей $[18$, с. 35-36]. Значения нитрификации при использовании технологии NT выше для посевов льна и ячменя в 2-3 раза по сравнению с традиционной технологией. Максимальная нитрификация отмечена в период колошения зерновых культур и выхода в фазу цветения льна в июне. При изменении агрофизических свойств почвы происходит нарушение не только питательного режима почв, но и выработки ферментов вследствие метаболической активности биоты почв. Активность почвенных оксидоредуктаз и гидролаз в верхнем слое почвы (0-10 см) с NT зависела от сохранения влаги в почве [19, с. 14-15]. По сравнению с традиционной технологией обработки почвы, наиболее тесные связи обнаружены между гидротермическими показателями и активностью $\beta$ - 
Мокриков Г.В., Минникова Т.В., Казеев К.Ш., Колесников С.И. 03.02.00 - общая биология Влияние запасов продуктивной влаги и количества атмосферных осадков на урожайность...

фруктофуранозидазы, активность которой, как известно из литературы, тесно связана с плодородием почв и содержанием гумуса [6, с. 416]. Похожие результаты получены А.В. Заушинценой с соавторами (2018) при сравнении разных технологий обработки чернозема обыкновенного Красноярской лесостепи, где повышенная влажность почвы при минимальной обработке и прямом посеве вызвала значительное увеличение целлюлозоразлагающей активности на $27-38 \%$ и почвенного дыхания на $17-24 \%$ [20, с. 4647]. Благоприятное влияние технологии прямого посева было подтверждено на бинарных посевах подсолнечника с донником и викой [21, с. 152-153]. Чернозем обыкновенный имел высокую активность каталазы и инвертазы под всеми выращиваемыми растительными культурами. При изучении бинарных посевов подсолнечника было выявлено, что активность оксидоредуктаз в целом снижается со снижением влажности в течение вегетационного периода, активность протеазы, напротив, повышается от июня к сентябрю.

Под различными сельскохозяйственными культурами оценивали количество атмосферных осадков и урожайность сельскохозяйственных культур. Сельскохозяйственные культуры различают по способам посева и выращивания (культуры сплошного сева и пропашные) и в связи с этим для каждой культуры учитывали период вегетации и сумму атмосферных осадков в течение этого периода. По потребности в критической влаге пропашные культуры, такие как подсолнечник, формируют мощную корневую систему, вследствие чего потребляют влагу из пахотного (0-22 см.) и подпахотного слоя почвы (глубже 22 см), а культуры сплошного сева, как, например, озимая пшеница, - в пахотном слое почвы (0-22 см).

\section{Цель и объекты исследования}

Цель нашего исследования - оценить влияние запасов продуктивной влаги и количества атмосферных осадков в весенне-летний и осенний период на урожайность сельскохозяйственных культур при использовании прямого посева в условиях Ростовской области.

Влияние технологии прямого посева на свойства почв исследовали в агроценозах Октябрьского района Ростовской области. Объектами исследования выбраны участки с прямым посевом (No-Till) и традиционной технологией обработки (традиционная технология).

Почвы относятся к черноземам обыкновенным разной мощности (Voronic Chernozems, WRB), степени выщелоченности от карбонатов и гумусированности [6, с. 416; 22, с. 342]. По технологии прямого посева черноземы обрабатываются на площади около 5 тысяч гектаров в течение 9 последних лет. Территория Октябрьского района Ростовской области расположена в регионе со значительными тепловыми ресурсами. Сумма положительных температур воздуха (выше $10^{\circ} \mathrm{C}$ ) составляет $3200^{\circ} \mathrm{C}$. Лето жаркое (температура июля $+24,3^{\circ} \mathrm{C}$ ), зима умеренно холодная (температура января $-2,5 \ldots-2,7^{\circ} \mathrm{C}$ ). В то же время большая часть Ростовской области относится к территории недостаточного и неустойчивого увлажнения. Среднемноголетнее количество осадков по справочным данным составляет 423 мм [23, с. 724 ; 24 , c. 183$]$.

\section{Материалы и методика исследований}

Посев сельскохозяйственных культур производился трактором Buhler Versatile 2375 + Great Plains NTA 3510 (10,7 м) и Case Magnum 315 + Great Plains NTA 3510 (10,7 м). Все сельскохозяйственные культуры высевались с междурядьем 19,1 см. Расход моторного топлива при NT - 26 л/га, при ТT - 74,1 л/га. При прямом посеве при всех операциях обработки почвы использовали технику, работающую на дизельном топливе, отвечающем международным стандартам по содержанию оксида углерода и азота. При этом расход дизельного топлива на основную обработку почвы при прямом посеве (NT) составляет 26 л/га, что в 3 раза меньше, чем при традиционной технологии (ТT). Наибольшие затраты наблюдали на стадии предпосевной обработки почв и уборки культур - 31 и 58\% соответственно, в то время как при TT основные затраты показаны на стадии основной обработки почвы - 44\% и уборке культур - 20\%. Поля с NT расположены на расстоянии 50-100 м от участков с ТT.

В 2014-2018 гг. было исследовано 28 полей с различными выращиваемыми культурами: озимые пшеница (Triticum aestivum L.) и ячмень (Hordeum vulgare L.), яровой ячмень (Hordeum sativum distichum), подсолнечник (Helianthus anпuиs L.), масличный лен (Linum usitatissimum L.), кориандр (Coriandrum sativum L.), нут (Cicer arietinum L.), рапс (Brassica napus L.). Исследования проводили в зернопропашном и зернотравяном восьмипольных севооборотах со следующим чередованием культур (в \% от занятой площади):

1) озимая пшеница + ячмень (100\%);

2) подсолнечник + многолетние бобовые травы $(80 \%)+$ сафлор (20\%);

3 ) озимая пшеница + ячмень (100\%);

4) кукуруза на зерно $(80 \%)+$ крестоцветные (рыжик, рапс, горчица) (20\%);

5) озимая пшеница (100\%);

6) зерновые бобовые (нут, чечевица, горох) (66\%) + крестоцветные (рыжик, рапс, горчица) (33\%);

7) озимая пшеница + ячмень $(100 \%)$;

8) лен (33\%) + кориандр (50\%) + гречиха (17\%).

По данным Федеральной государственной службы статистики в 2018 г., площади посевов озимой пшеницей и подсолнечником в Ростовской области относительно других регионов России занимают 9,3 и $10,3 \%$ соответственно [25]. В Ростовской области озимой пшеницей занято более $43-45 \%$ пахотных земель, подсолнечником - около 15-20\%. Озимую пшеницу относят к однолетним зерновым культурам сплошного сева, а подсолнечник - к пропашным культурам. Культуры различаются физиологическими особенностями строения корневой системы, потребностью во влаге, фазами развития, посева семян и агротехническими манипуляциями. Культуры различаются по периоду максимальной вегетации. У озимой пшеницы это фазы выхода в трубку, колошение и цветение и восковой спелости: с апреля по июнь. У подсолнечника эти фазы отличаются значительно на фазе всходов, формирования корзинки, период налива и спелости: с июня по сентябрь. Кроме того на созревание семян подсолнечника и озимой пшеницы влияет запасы продуктивной влаги и количество атмосферных осадков в весенне-летний и осенний период. 
Мокриков Г.В., Минникова Т.В., Казеев К.Ш., Колесников С.И.

Влияние запасов продуктивной влаги и количества атмосферных осадков на урожайность... $03.02 .00-$ общая биология

Данные по урожайности озимой пшеницы и подсолнечника при прямом посеве и отвальной вспашке представлены агропроизводителями и по данным Федеральной государственной службы статистики России [25]. Помесячное количество атмосферных осадков за 2014-2018 гг. представлено согласно данным метеостанции Ростов-на-Дону.

Статистическая обработка данных проводилась с использованием пакета программ Statistica 12.0.

\section{Результаты исследований} и их обсуждение

\section{Урожайность}

озимой пшеницы и подсолнечника

\section{по России и Ростовской области}

Урожайность сельскохозяйственных культур в России за последние годы претерпела существенную динамику. Валовые сборы озимой пшеницы за последние пять лет по России существенно варьировали: в 2014, 2015 г. - 59,7 и 61,8 млн тонн, а в 2016-

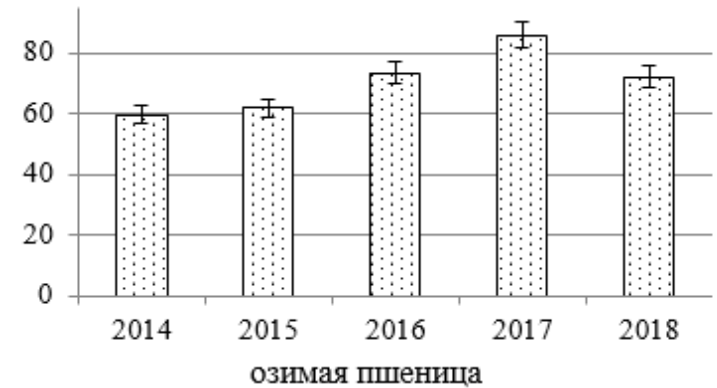

2017 гг. - 73,3-86,0 млн тонн, в 2018 г. - 72,1 млн тонн (рис. 1). По валовым сборам подсолнечника наблюдали схожую картину: в 2014, 2015 гг. - 8,5 и 9,2 млн тонн, а в 2016 и 2017 гг. $-11,0$ и 10,5 млн тонн.

При площади посевных площадей озимой пшеницы с 2016 по 2018 гг. варьируется в диапазоне 27,3-27,9 тыс. га (рис. 2). Площадь посевов подсолнечника в 2018 г. увеличилась по сравнению с 2014 и 2015 гг. на 18 и 16\% соответственно. За 2014 2018 гг. наблюдали рост площадей посевов подсолнечника в РФ. Урожайность подсолнечника за этот период возросла на 20-48\%.

Этот факт может быть обусловлен количеством осадков за период вегетации и качественным подбором семенного материала и применяемых гербицидов. Урожайность озимой пшеницы с 2014 по 2017 гг. возросла на 17-44\%. В 2018 г. по всей России наблюдали спад урожайности озимой пшеницы на 19\%, вызванный весенне-летней засухой.

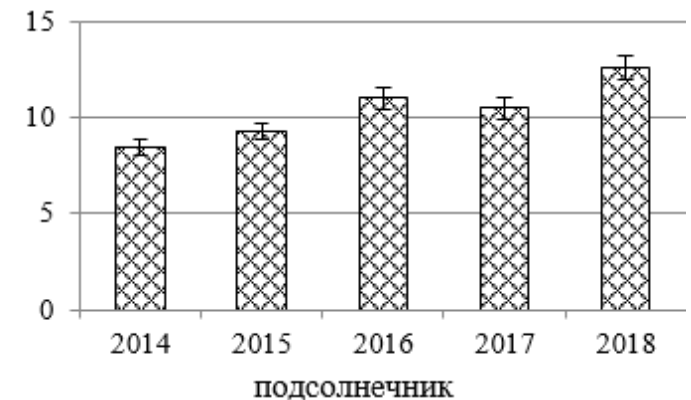

Рисунок 1 - Валовые сборы озимой пшеницы и подсолнечника в хозяйствах всех категорий Российской Федерации за 2014-2018 гг. по данным Росстата, млн тонн
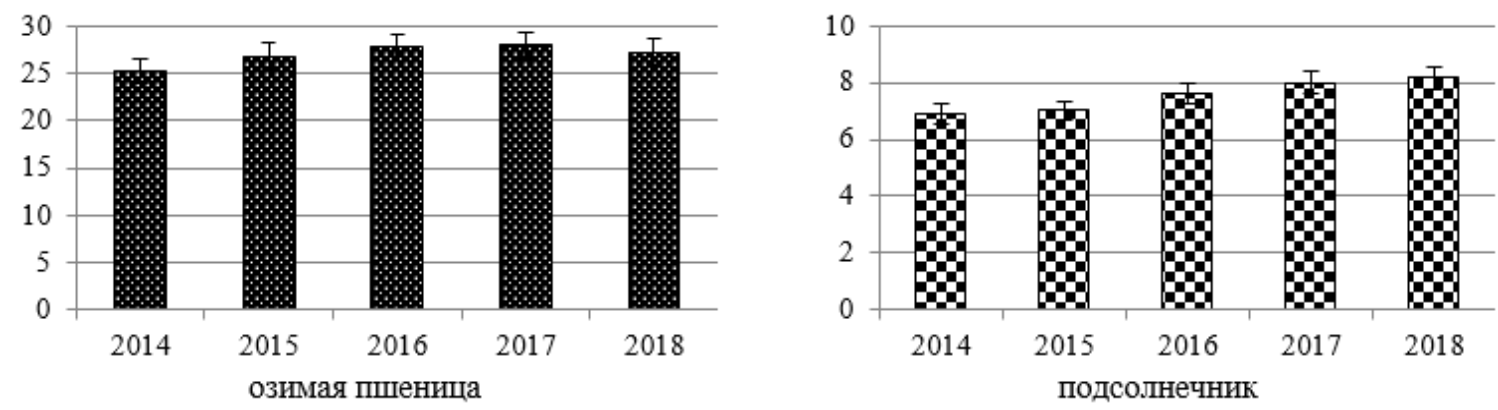

Рисунок 2 - Посевные площади озимой пшеницы и подсолнечника в хозяйствах всех категорий Российской Федерации за 2014-2018 гг. по данным Росстата, тыс. гектаров

Атмосферные осадки в Ростовской области

Суммарное годовое количество осадков в Ростовской области в 2014, 2015, 2016, 2017 и 2018 годах составило 520, 522, 707, 567 и 722 мм (рис. 3). По выпавшему количеству осадков 2014 и 2015 гг. считают равномерно увлажненными в вегетационный сезон пшеницы - 218 и 228 мм в 2014 и 2015 гг. соответственно. На порядок меньшее увлажнение наблюдали в сезон вегетации подсолнечника на 65 и 25 мм в 2014 и 2015 гг. соответственно.

В 2016 и 2017 гг. количество осадков в период вегетации озимой пшеницы составило 237 и 185 мм, а подсолнечника - 137 и 58 мм. По климатическим условиям в 2016 г. показано превышение количества осадков на $66 \%$ по сравнению с нормой, в 2017 г. на 34\%. По количеству осадков 2016 год был очень влажным за счет осадков в мае и июле -187 и 63 мм. В 2016 года в вегетационный сезон озимой пшеницы выпало - 237 мм, а подсолнечника - 169 мм. В вегетационный сезон 2017 г. озимой пшеницы выпало
185 мм, подсолнечника - 105 мм. Наибольшее количество осадков выпало после сезонов критической вегетации подсолнечника и озимой пшеницы в октябре, ноябре и декабре 2017 г. - 51, 63, 104 мм соответственно. При годовом высоком количестве осадков в Ростовской области (722 мм) в 2018 году период вегетации озимой пшеницы был очень засушливым: в критический для нее период роста с апреля по июнь выпало на 79-83\% меньшее количество осадков, чем в предыдущие годы. Недостаток осадков весной и в начале лета 2018 г. привел к уменьшению урожайности озимой пшеницы по всей России на $17 \%$, в том числе по Ростовской области - на $10 \%$. В вегетационный сезон подсолнечника (с июня по сентябрь) выпало достаточно осадков для формирования и созревания семян - 197 мм. Если по сравнению с предыдущим годом по России наблюдали рост урожайности подсолнечника на 25\%, то в Ростовской области наблюдали незначительное снижение - на $10 \%$. 
Мокриков Г.В., Минникова Т.В., Казеев К.Ш., Колесников С.И. 03.02.00 - общая биология Влияние запасов продуктивной влаги и количества атмосферных осадков на урожайность...

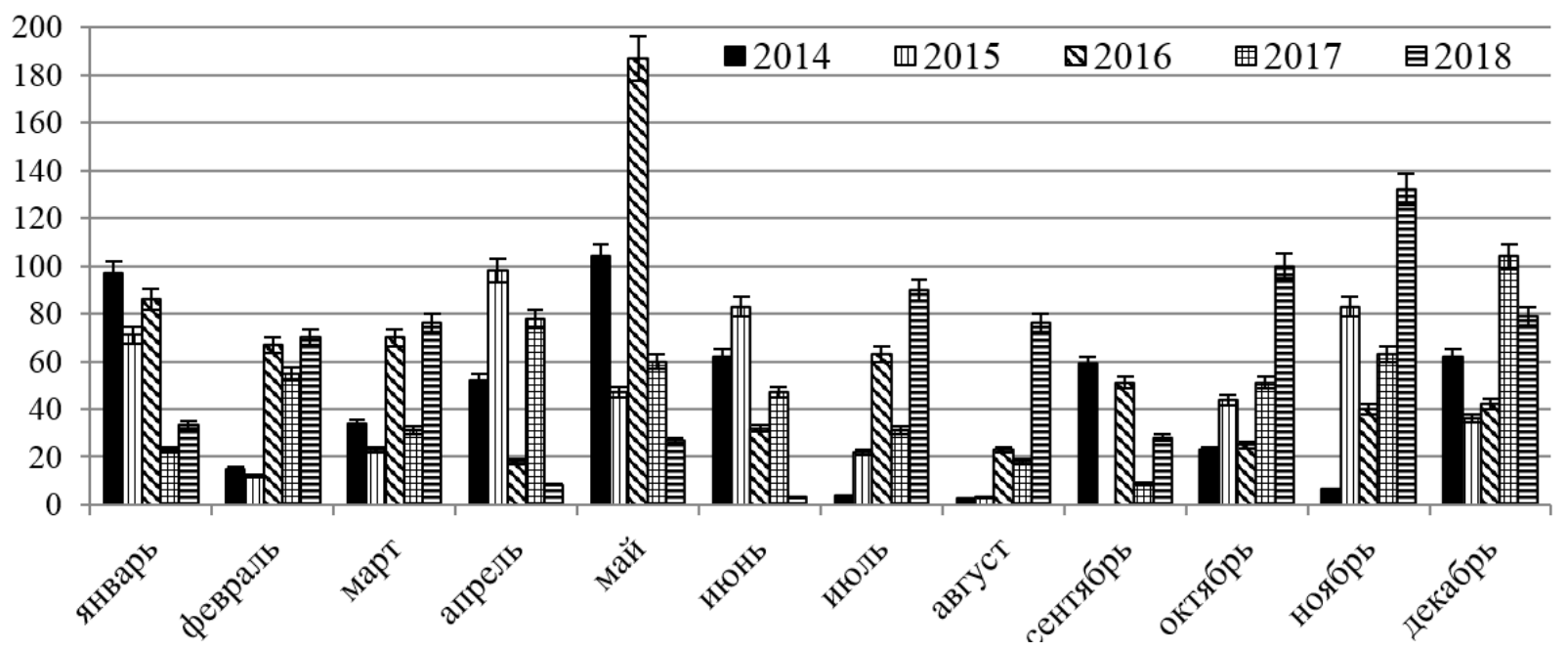

Рисунок 3 - Количество атмосферных осадков в Октябрьском районе Ростовской области за 2014-2018 гг. по данным метеостанции Ростов-на-Дону

При прямом посеве в 2014 и 2015 гг. и количестве осадков 520-522 мм урожайность озимой пшеницы в Ростовской области с NT была выше, чем при ТT на 51 и 114\% (табл. 1). В 2016-2017 гг. урожайность озимой пшеницы в Ростовской области с NT была выше, чем с ТТ на 36 и 26\%, при общей высокой урожайности озимой пшеницы по региону.

Таблица 1 - Урожайность основных сельскохозяйственных культур в Ростовской области при прямом посеве (NT) и традиционной технологии (ТT) (2014-2018 гг.), ц/га

\begin{tabular}{|c|c|c|c|c|c|c|}
\hline $\begin{array}{c}\text { Сельско- } \\
\text { хозяй- } \\
\text { ственная } \\
\text { культура }\end{array}$ & $\begin{array}{c}\text { Техно- } \\
\text { логия } \\
\text { обра- } \\
\text { ботки } \\
\end{array}$ & $\stackrel{ \pm}{\stackrel{d}{d}}$ & in & 웅 & 공 & $\stackrel{\infty}{\stackrel{\sim}{\sim}}$ \\
\hline \multirow{2}{*}{$\begin{array}{l}\text { Озимая } \\
\text { пшеница }\end{array}$} & NT & 36,3 & 50,7 & 54,2 & 56,0 & 29,8 \\
\hline & TT & 24,1 & 23,7 & 39,0 & 44,5 & 41,0 \\
\hline \multirow{2}{*}{$\begin{array}{l}\text { Подсол- } \\
\text { нечник }\end{array}$} & NT & 18,5 & 27,2 & 27,5 & 27,0 & 25,0 \\
\hline & TT & 14,0 & 14,0 & 14,3 & 15,7 & 19,7 \\
\hline
\end{tabular}

В 2018 году за счет засухи в весенне-летний период (апрель-июнь) урожайность озимой пшеницы снизилась на 16\% по сравнению с ТТ и на $46 \%$ по сравнению с урожаем 2017 года. Себестоимость озимой пшеницы в высокоурожайные 2015, 2016 и 2017 гг. была ниже, чем себестоимость по ТТ на 41, 45 и 10\% соответственно. В 2014 и 2015 гг. урожайность подсолнечника на исследуемой территории при NT была выше, чем при традиционной технологии на 32 и 92\% соответственно. Подсолнечник, выращенный на почвах с NT в Ростовской области в 2016 и 2017 гг., также имел высокую урожайность, особенно в 2016 году на 92\%, по сравнению с ТT. Несмотря на недостаток влаги в вегетационных сезонах 2014, 2015 и 2017 гг., урожайность подсолнечника при прямом посеве варьировала в диапазоне 27,0-27,2 ц/га. Урожайность подсолнечника в 2018 году по сравнению с 2017 годом снизилась на $10 \%$, но превышала урожайность при отвальной вспашке на $27 \%$.

Сохранение стерни, образование мульчирующего слоя, улучшение структуры почвы и сохранение влаги в почве при NT снижает вероятность возникновения эрозии в почве. Снижение потребления топлива при прямом посеве в 3 раза позволяет экономить мо- торное топливо, что приводит к снижению выбросов парниковых газов. Сокращение стадий обработки почвы при NT снижает переуплотнение почв техникой, что также благоприятно сказывается на физическом и биологическом состоянии почв. Учитывая снижение затрат на топливные ресурсы на всех стадиях обработки подсолнечника, при прямом посеве себестоимость была ниже на 35-68\%, чем при традиционной технологии.

Ранее в условиях производственного эксперимента в агроценозах Октябрьского района Ростовской области в среднем за два года наибольшая урожайность была получена при выращивании озимой пшеницы по технологии прямого посева (4,19 т/га), что $18 \%$ выше, чем при традиционной технологии [26, c. 3-4]. Лучшие экономические показатели производства были получены при выращивании озимой пшеницы по NT, что обусловлено получением наименьшей себестоимости зерна и наивысшей рентабельности производства. Там же было установлено повышение урожайности подсолнечника на 49\% $(22,5$ ц/га) в варианте NT, по сравнению с отвальной вспашкой [27, с. 46-47]. Это связано с повышением запасов влаги в почве с прямым посевом. В ранневесенний период запасы влаги в слое почвы 0-150 см в варианте NT были выше на 15,5 мм, а к севу подсолнечника - на 20,4 мм. К основному показателю восстановления почв при NT относят накопление гумуса, как показателя плодородия, за счет деятельности почвенной микробиоты [28, с. 1052-1053]. При высоком содержании гумуса и сохранении доступной влаги в почве при прямом посеве под различными сельскохозяйственными культурами улучшаются физические свойства, повышается численность почвенных азотфиксирующих и целлюлозолитических бактерий; стимулируется ферментативная активность почв [21, с. $152-153 ; 29$, с. $96 ; 30$, с. $72-73 ; 31$, p. 189-190; 32, p. 260-262].

\section{Заключение}

Технология прямого посева позволяет сохранить запасы влаги в почве в течение вегетационного сезона и улучшает агрофизическое состояние почв, что способствует повышению урожайности озимой пшеницы и подсолнечника. Применение этой ресурсосберегающей технологии прямого посева позволяет 
улучшить экологическое состояние почв за счет активизации микробиоты, накопления органического вещества, сохранения влаги и улучшения структурного состояния. Технология прямого посева приводит к снижению затрат за счет значительной экономии моторного топлива. В многолетней динамике 2014-2018 гг. при использовании прямого посева показано снижение себестоимости озимой пшеницы и подсолнечника на $41-45 \%$ и $32-92 \%$ по сравнению с традиционной технологией.

\section{Список литературы:}

1. Дридигер В.К., Кулинцев В.В., Стукалов Р.С., Гаджиумаров Р.Г. Динамика изменения агрофизических свойств почвы при возделывании полевых культур по технологии No-Till // Известия Оренбургского государственного аграрного университета. 2018. № 5 (73). С. 35-38.

2. Зеленский Н.А., Зеленская Г.М., Мокриков Г.В., Шуркин А.Ю. Плодородие почвы: настоящее и будущее нашего земледелия // Земледелие. 2018. № 5. C. 4-7.

3. Ivelic-Sáez J., Zúñiga F., Valle S., López I., Dec D., Dörner J. Functional resistance and resilience of the pore system of an andisol exposed to different strategies of pasture improvement under sheep grazing // Soil Science and Plant Nutrition. 2015. Vol. 15. P. 663-679.

4. Zúñiga F., Ivelic-Sáez J., López I., Huygens D., Dörner J. Temporal dynamics of the physical quality of an Andisol under a grazing system subjected to different pasture improvement strategies // Soil and Tillage Research. 2015. Vol. 145. P. 233-241.

5. Soane B.D., Ball B.C., Arvidsson J., Basch G., Moreno F., Roger-Estrade J. No-till in northern, western and south-western Europe: A review of problems and opportunities for crop production and the environment // Soil and Tillage Research. 2012. Vol. 118. P. 66-87.

6. Вальков В.Ф., Денисова Т.В., Казеев К.Ш., Колесников С.И., Кузнецов Р.В. Плодородие почв и сельскохозяйственные растения: экологические аспекты. Ростов-на-Дону: Изд-во ЮФУ, 2008. 416 с.

7. Байбеков Р.Ф. Природоподобные технологии основа стабильного развития земледелия // Земледелие. 2018. № 2. С. 5-8.

8. Шеховцов Г.А., Чайкина Н.Н. Мониторинг плодородия почв // Земледелие. 2018. № 6. С. 21-26.

9. Palm C., Blanco-Canqui H., Declerck F., Gatere L., Grace P. Conservation agriculture and ecosystem services: an overview // Agriculture Ecosystems \& Environment. 2014. Vol. 187. P. 87-105.

10. Tebrügge F., Düring R.-A. Reducing tillage intensity - a review of results from a long-term study in Germany // Soil \& Tillage Research. 1999. Vol. 53 (1). P. 15-28.

11. Справочник по прямому посеву на открытых грунтах - специальное издание Кларин. Аргентина. Artes Gráficas Rioplatense S.A, 2004. 234 p.

12. Кирюшин В.И. Проблемы минимизации обработки почвы: перспективы и задачи исследований // Земледелие. 2013. № 7. С. 3-6.

13. Uteau D., Pagenkemper S., Peth S., Horn R. Root and time dependent soil structure formation and its influence on gas transport in the subsoil // Soil and Tillage Research. 2013. Vol. 132. P. 69-76.

14. Русанов А.М., Милановский Е.Ю., Верхошенцева Ю.П., Воропаев С.Б., Анилова Л.В. Физические свойства черноземов обыкновенных на сопредельных с лесными массивами участках степных ландшафтов // Почвоведение. 2012. № 7. С. 763-769.

15. Хитров Б.Н., Чечуева О.А. Влияние распашки и орошения на макроструктуру черноземов // Почвоведение. 1994. № 6. С. 106-114.

16. Bogunovic I., Pereira P., Kisic I., Sajko K., Sraka M. Tillage management impacts on soil compaction, erosion and crop yield in Stagnosols (Croatia) // Catena. 2018. Vol. 160. P. 376-384.

17. Зональные системы земледелия Ростовской области на 2013-2020 годы / под общ. ред. В.Н. Василенко. Ч. 2 / С.Г. Бондаренко и др. Ростов-на-Дону: Министерство сельского хозяйства и продовольствия Ростовской области, 2013. 243 с.

18. Минникова Т.В., Мокриков Г.В., Казеев К.Ш., Акименко Ю.В., Колесников С.И. Влияние технологии No-Till на нитрифицирующую активность черноземов Ростовской области // Агрохимия. 2017. № 9. C. 33-38.

19. Минникова Т.В., Мокриков Г.В., Казеев К.Ш., Акименко Ю.В., Колесников С.И. Оценка зависимостей между гидротермическими показателями и ферментативной активностью черноземов Ростовской области при использовании различных агротехнологий // Агрофизика. 2018. № 1. С. 9-17.

20. Заушинцена А.В., Романов В.Н., Кожевников Н.В. Влияние ресурсосберегающих способов основной обработки чернозема обыкновенного на показатели общей биологической активности и урожайность зерновых культур // Самарский научный вестник. 2018. Т. 7, № 3 (24). С. 41-48.

21. Минникова Т.В., Мокриков Г.В., Казеев К.Ш., Акименко Ю.В., Колесников С.И. Оценка ферментативной активности черноземов Ростовской области под бинарными посевами подсолнечника // Известия Тимирязевской сельскохозяйственной академии. 2017. № 6. С. 141-155.

22. Шишов Л.Л., Тонконогов В.Д., Лебедева И.И., Герасимова М.И. Классификация и диагностика почв России. Смоленск: Ойкумена, 2004. 342 с.

23. Научно-прикладной справочник по климату СССР. Вып. 13. Волгоградская, Ростовская, Астраханская области, Краснодарский, Ставропольский края, Калмыцкая, Кабардино-Балкарская, ЧеченоИнгушская, Северо-Осетинская АССР. Л.: Гидрометеоиздат, 1990, $724 \mathrm{c.}$

24. Хрусталев Ю.П., Василенко В.Н., Свисюк И.В., Панов В.Д., Ларионов Ю.А. Климат и агроклиматические ресурсы Ростовской области. Ростов-на-Дону: Батайское кн. изд-во, 2002. 183 с.

25. Федеральная служба государственной статистики [Электронный ресурc] // http://gks.ru/wps/wcm/ connect/rosstat_main/rosstat/ru/statistics/publications/cat alog.

26. Зеленский Н.А., Зеленская Г.М., Мокриков Г.В., Река Ю.В. Выращивание озимой пшеницы по технологии прямого посева в условиях Ростовской области // Современные проблемы науки и образования. 2012. № 6. С. 1-5.

27. Зеленский Н.А., Зеленская Г.М., Шуркин А.Ю. Урожайность подсолнечника при различных технологиях обработки почвы // Защита и карантин растений. 2014. № 9. С. 44-47.

28. Кудеяров В.Н. Современное состояние углеродного баланса и предельная способность почв к 
Мокриков Г.В., Минникова Т.В., Казеев К.Ш., Колесников С.И. 03.02.00 - общая биология Влияние запасов продуктивной влаги и количества атмосферных осадков на урожайность..

поглощению углерода на территории России // Почвоведение. 2015. № 9. С. 1049-1060.

29. Акименко Ю.В., Мокриков Г.В., Казеев К.Ш., Колесников С.И. Влияние технологии прямого посева на микробиологические свойства черноземов. Ростов-на-Дону: Изд-во ЮФУ, 2016. 96 с.

30. Мокриков Г.В., Казеев К.Ш., Акименко Ю.В., Колесников С.И. Влияние технологии прямого посева на эколого-биологические свойства черноземов // Известия высших учебных заведений. Северо-Кавказский регион. 2017. № 2. С. 68-74.

31. Kazeev K.S., Mokrikov G.V., Akimenko Y.V., Kolesnikov S.I. Effect of no-till on the physical properties of south Russia soil // International Multidisciplinary
Scientific GeoConference Surveying Geology and Mining Ecology Management, SGEM 2017. 2017. Vol. 17 (32). P. 185-192. DOI: 10.5593/sgem2017/32/S13.025.

32. Mokrikov G.V., Kazeev K.Sh., Akimenko Yu.V., Myasnikova M.A., Kolesnikov S.I. Influence of the NoTill technology on the enzymatic activity of different chernozems of Southern Russia // 18th International Multidisciplinary Scientific GeoConference SGEM 2018: Conference Proceedings. 2018. Vol. 18. P. 257-264.

Статья публикуется при поддержке Министерства образования и науки Российской Федерации (5.5735.2017/8.9) и Президента Российской Федерации (НШ-3464.2018.11).

\title{
INFLUENCE OF DIRECT SEEDING ON THE YIELD OF AGRICULTURAL CULTURES IN THE ROSTOV REGION
}

(C) 2019

Mokrikov Gregory Vasilyevich, candidate of agricultural sciences, researcher of Ecology and Nature Management Department of Academy of Biology and Biotechnology named after D.I. Ivanovsky Minnikova Tatiana Vladimirovna, junior researcher of Ecology

and Nature Management Department of Academy of Biology and Biotechnology named after D.I. Ivanovsky Kazeev Kamil Shagidullovich, doctor of geographical sciences, professor of Ecology and Nature Management Department of Academy of Biology and Biotechnology named after D.I. Ivanovsky

Kolesnikov Sergey Ilyich, doctor of agricultural sciences, professor, head of Ecology and Nature Management Department of Academy of Biology and Biotechnology named after D.I. Ivanovsky Southern Federal University (Rostov-on-Don, Russian Federation)

Abstract. Tillage technologies that promote resource conservation and increase crop yields, especially in conditions of dry climate, are increasingly being introduced into the Russian agriculture. However, taking into account a diversity of soil and climatic conditions in Russia, it is necessary to study the agro-ecological state of agro landscapes. In Russia, in recent years, an increase in the yield of winter wheat and sunflower has been observed. From 2014 to 2018 in production conditions in the Rostov Region, the effect of direct sowing technology (No-Till) on the yield of winter wheat and sunflower was studied. The yield of sunflower and winter wheat largely depended on the amount of precipitation during the critical growing season of each agricultural crop. In 2014-2017 the yield of winter wheat in agrocenoses using direct sowing technology increased by $26-114 \%$, sunflower by $27-92 \%$ compared with the traditional technology. The authors show that direct seeding compared to traditional technology of dump plowing (traditional tillage) contributes to saving motor fuel, increasing crop yields and lowering the cost of the main crops of the Rostov Region: winter wheat and sunflower.

Keywords: ecosystem; green technology; nature-like technologies; agrocenoses; humidity; growing season; ordinary chernozem; direct seeding; zero technology; traditional tillage; resource saving; nature-like technologies; agrocenoses; soil condition; winter wheat; sunflower; yield; fertility.

УДК 581.9

DOI 10.24411/2309-4370-2019-11112

Статья поступила в редакцию 04.09.2018

\section{ИЗУЧЕННОСТЬ ГАЛОФИТНОЙ РАСТИТЕЛЬНОСТИ ПЕНЗЕНСКОЙ ОБЛАСТИ И ЕЕ ОХРАНА} (C) 2019

\author{
Новикова Любовь Александровна, доктор биологических наук, доцент, \\ профессор кафедры общей биологии и биохимии \\ Пензенский государственный университет (2. Пенза, Российская Федеращия) \\ Васюков Владимир Михайлович, кандидат биологических наук, \\ научный сотрудник лаборатории проблем фиторазнообразия \\ Институт экологии Волжского бассейна РАН (2. Тольятти, Самарская область, Российская Федерация) \\ Горбушина Татьяна Викторовна, кандидат сельскохозяйственных наук, старший научный сотрудник \\ Государственный природный заповедник «Приволжская лесостепь» (2. Пенза, Российская Федераиия)
}

Аннотащия. Всего в Пензенской области в настоящее время выявлено и описано 15 участков с засоленными почвами, из которых только 2 имеют статус памятника природы: «Солонцовая степь» в Лунинском районе и «Даниловская солонцовая поляна» в Малосердобинском районе. Предлагаем включить в существующую систему ООПТ Пензенской области в качестве памятников природы еще 13 урочищ: в Колышлейском районе - «Жмакинский солонец», «Кайсаровский солонец»; в Лопатинском - «Литвиновский солонец»; в Малосердобинском - «Чунакская солонцовая поляна», «Корзовая лощина»; в Неверкинском - «Келлеровский солонец», «Мансуровский солонец», «Карноварский солонец»; в Пензенском - «Ольшанский со- 